\title{
A Method to Determine the Optimal Intensity of Oral Anticoagulant Therapy
}

\author{
F. R. Rosendaal ${ }^{1,2}$, S. C. Cannegieter ${ }^{2}$, F. J. M. van der Meer ${ }^{2}$, and E. Briët ${ }^{2}$ \\ From the ${ }^{1}$ Department of Clinical Epidemiology, ${ }^{2}$ Hemostasis and Thrombosis Research Center, \\ University Hospital Leiden, The Netherlands
}

\begin{abstract}
Summary
Oral anticoagulant therapy has been shown to be effective for several indications. The optimal intensity of anticoagulation for each indication, however, is largely unknown. To determine this optimal intensity, randomised clinical trials are conducled in which two target levels of anticoagulation are compared. This approach is incfficient, since the choice of the target levels will be arbitrary. Moreover, the achieved intensity is not taken into account.

We propose a method to determine the optimal achicved intensity of anticoagulation. This method can be applied within a clinical trial as an "efficacy-analysis", but also on data gathered in day-to-day patient carc.

In this method, INR-specific incidence rates of events, either thromboembolic or hemorrhagic, are calculated. The numerator of the incidence rate is based on data on the INR at the time of the cvent. The denominator consists of the pcrson-time at each INR value, summed over all patients, and is calculatcd from all INR measurements of all patients during the follow-up interval. This INR-specific person-time is calculated with the assumption of a linear increase or decrease between two consecutive INR determinations. Since the incidencc rates may be substratificd on covariates, efficient assessment of the effects of other factors (e.g. agc, scx, comedication) by multivariate regression analysis becomes possible.
\end{abstract}

This method allows the determination of the optimal pharmacological effects of anticoagulation, which can form a rational starting point for choosing the target levels in subscquent clinical trials.

\section{Introduction}

Several randomiscd clinical trials have been conducted, or are in progress, in which two intensities of oral anticoagulant therapy are compared prospectively. This unfolding array of trial activity presents two problems to the field. First, it is unclear how the target levels of anticoagulation which are contrasted in these trials are predefined. Up to now, the choice of target levcls is largely arbitrary and therefore a sheer infinite series of "trial and error" will inevitably follow. Second, the actually achieved intensity of anticoagulation is not taken into account. At best, the achieved intensity will fluctuate around the target level in a way that is dependent on particular patient characteristics and local organisation of anticoagulation monitoring. These randomiscd trials therefore offer only little information about the optimal intensity of anticoagulation, for the pharmacologic effect and the effects of extrancous factors influcncing anticoagulation are inextricably intertwined.

Coriespondence to. D1. F. R. Rosendaal, Department of Clinical Epidemiology, Bldg 1, CO-P, Univessity Hospital Leiden, P.O Box 9600, NL-2300 RC Lerden, The Netherlands
The efficacy of oral anticoagulant treatment has been uncquivocally demonstrated for several indications. These include short term prophylaxis for venous thrombosis in high-risk situations, and short term treatment after an episode of deep venous thrombosis or pulmonary embolism. Long term treatment has becn shown to be beneficial in patients with mechanical heart valves, in patients with atrial fibrillation, and in patients suffering from coronary artery discasc (1). For all these indications anticoagulant treatment has proved to be effective compared to placebo. The next question is which intensity of anticoagulation bffers the best benefit-risk-ratio, i.e., the optimal balance between thrombosis prevention and the occurrence of bleeding complications. This issue has gained relevance since the development and implementation of the ISI/INR system, which renders it possible to cxpress the anticoagulation level, as measured routinely and locally with one of the many available thromboplastins, in one standardised measure (2).

Some of the trials in which two levels of anticoagulation were compared, for instance in patients with bioprostheses of the heart valves (3) and in paticnts with mechanical heart valves (4), have shown target levels lower (i.c. less anticoagulation) than those usually recommended to be as effective and as safe as the higher target levels. All these trials arc obviously of the intention-totreat typc, sincc it is impossible to maintain a completely stablc anticoagulant effect at the target level in all patients all of the time. Extraneous factors as patient's compliance, physician's experience and variations in cumarin sensitivity in the individual patient will cause differences between the achieved intensity and the target level. Therefore, little insight is obtained about the risk of untoward effects at different intensitics of anticoagulation.

This can be illustrated by the study of Saour et al. (4), who compared target levels of INR 2.65 and INR 9.0 in patients with mechanical heart valves. In this study 33 thromboembolic cvents and 13 major bleedings were observed. The thromboembolic events were equally divided over both treatment groups, whereas most bleedings occurred in the group with the high target level. However, two-thirds of all thrombocmbolic events occurred at anticoagulation intensities (at the time of the event) below INR 2.65 and all occurred at intensities below INR 9.0. Similarly, in ninc of the 13 patients with major bleeding, the anticoagulation intensity exceeded INR 14 at the time of the event. So, most complications occurred in patients in whom the achieved intensity of anticoagulation at the time of the event was far from the intended intensity. In addition, onc may question the generalisability from the results of a study of this design to other centers, since patient compliance and quality of anticoagulation monitoring may be quite different.

We propose a method to determine the optimal achieved intensity of anticoagulation. In our vicw, this method should not replacc, but precede trials in which target levels are compared, since knowledge of this optimal achieved intensity offers a rational starting point for setting the target levels in subsequent trials. In addition, our method will yield insight into the variability 
at different taiget levels in a care system which is dedicated but still belongs to medical routine

\section{Method}

The pioposed method involves the calculation of incidence rates of both types of untowatd cvents (thiombocmbolism and blecding) 101 ditferent achieved intensities of anticoagulation To peiform these calcu lations, a study time fiame has to be detined over which a cohoit of patients is observed The required intormation include the dates of all prothiombin time assessments and the iesults of these measurements dunng the obseivation time, as well as the dates of all event occuirences and the prothrombin times at the time of the events Covariates, either general such as age and gender or specific such as hypertension, atilal fibillation or co medication may be iegistered and incorporated by stiatıfied analysis or multivariate modelıng by Poisson icgicssion Betorc desctibing the specific application of the calculation of incidence rates in anticoagulated patients, we will discuss the concepts of incidence 1 ates and the categoisation of incidence $r$ ates

\section{Incidence Rates}

Mathematically, the incidence 1 ate (Incidence density or hazaid $1 \mathrm{dtc}$ ) is the instantancous probability of an event occurience The average incidence rate is the number of events divided by the obseivation time, ususally expiessed in patient-ycais It appioximates the instantancous incidence sate by the assumption that over short observation intervals the probability of disease is proportional to the observation time, I e, 10 patients tollowed tor 2 years will yield the same incidence as 20 patients followed for 1 yedi Under this assumption, the incidence tate is easily calculated by determining the number of events and dividing this tiguic by the sum of the obseivation times of all patients in the cohot (5) Fol cach individual patient, the obseivation time is counted tiom his entiy in the study untıl enthe the end of the study time fiame or the time of an event, whichever occuis tust The probability of an event over a certain time inteival (cumulative incidence) can be deived tiom the incidence late by a simple exponential tianstormation $(5,6)$

\section{Categonsation of the Observation Time}

In the simplest form, the incidence is calculated for one, unstiatified coholt, by dividing the number of events by the sum of the obseivation tumes of all patients in the cohoit A first extension is stiditication over

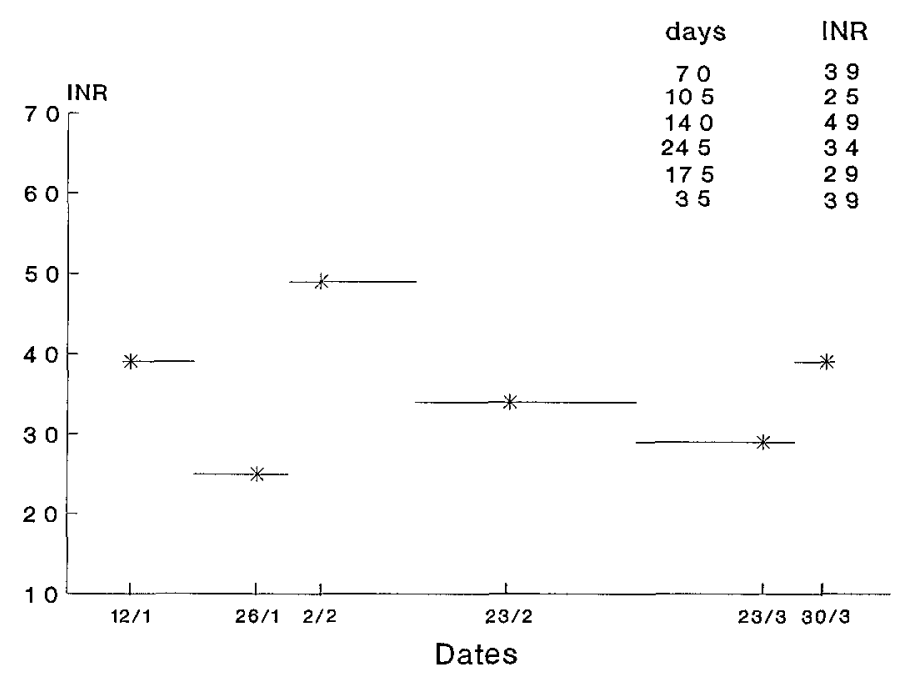

Fig 1 Allocation ol peison-tıme at diffeicnt INRs Six prothiombin time assessments and the dates of these assessments are shown for one patient The tıme elapsed between two measurements is divided over the INRs of these two assessments as indicated in the upper 11 ght The peison-time will subsequently be divided over the piedefined cells, i e, INR 2 5-2 9 280 days INR 30-34 245 days, INR 35-39 105 days and INR 4 5-4 9140 days fixed covarides, such as sex In this case all men contubute peison time only to the male stiatum and all women only to the female sttatum, with the 1 esult of two sex-spectic incidence tates

Since, however the only constituents of the incidence 1 ates ale the stratum-specific number of cvents, and the stidtum-specitic totd observa tion ume, it is not iequired that patients only contubute patient-tume to one stiatum When stiatification is peitormed on unfixed covaliates, such as calendat-pertod or age as is usually done to allow standardised compaison of two incidence tates, one patient may contisbute peisontime to several stiata For instance, if 5-year age categoi ics ate used and 10-ycar calendar time periods, a patıent followed for 5 years, staiting in 1988 at agc 42 will contibutc 2 ycais peison timc to the ccll [40-44 years, 1980-1989], 1 yedi to the cell [40-44 yeals, 1990-2000] and 2 years to the cell [45-49 years, 1990-2000] Age- and calenda1pertod specitic incidence idtes are subsequently calculated as the number of events within each cell, divided by the total obseivation time in each cell, which is derived fiom several patients

\section{Application to the Level of Anticoagulation}

Fully analogous to the catcgoisation of the peison tıme in cells deter mined by age scx and calenda periods, the obscivation tıme may be bioken down in cells of the achieved level of anticoagulation The incidence 1 ate of events dt each level of antucoagulation is again calculated as the ratio of the number of events occuining at a patticulat intensity, over the summed peison time at that intensity

\section{Events at Each Level (Incidence Numerator)}

Dependent on the events the study is almed at, a system has to be set up in which all events ate icgistered It scems most piactical to limit the study to severe complications i c those that iequile hospitalisation or lead to death Ideally, one has to know the intensity of anticodgulation at the time of the event In case of hospitalisation, a piothiombin tıme will usually be pertolmed When this has not becn done the only appioxima tion of the anticoagulation level a the time of the event is that of the last measurement betorc the event occuled

\section{Calculation of the Observatton Time for Different Levels (Incidence Denominator)}

For each paticnt, prothiombin times have been measured at tixed or vau rable intervals, the Iength of which time intervals is known We assume that the INR value between two measur ements will vaty lincarly tiom the value of the tisst, to the value of the sccond measuiement $W_{1}$ th this assumption, two approaches may be employed to allocate the person-time between two measuicments to particular INR values The most simple appioximation is to divide the time between two measuiement in halves, and allocate the turst halt to the INR value of the fust, and the second halt to the INR valuc of the second measuicment So, if a 2 -weck interval is bounded by a prothrombin tıme of 36 INR as the tılst, and 43 INR as the second measurement, 1 week of person-tume is allocated to 36 INR, and 1 week to 43 INR This is illustiated by Fig 1 Subsequenily the person-time at each INR value is summed ove1 all measuicments of all patients, and then grouped into cells of 05 or 10 INR Although in this appioximation the INR is ticated as if it changes instantly hallway between two measurements, over large numbers it yiclds a tail approach to the assumption of a lincal incicase or deciease (Fig 2)

A second, moic accurate appioach is to divide the time between two medsurcments in days, and to use small steps of 01 INR over the range of the time interval In this appioach, the INR is tteated as giddually incieasing or decieasing over the interval in the example above, 2 days ale allocated to an INR of 36,2 days to an INR of 37 , and so on Subsequently, the peison time of these small steps is collapsed into laiger cells of 05 or 10 INR and then summed over all patients We have developed software to peilorm these calculations on a peisonal computc1'

Fig 2 shows the 1csults of the application of both appioaches to the data of 392 patients with mechanical heart valves who visited the Leiden Thiombosis Selvice between 1985 and 1991 (total obseivation 1ıme

\footnotetext{
1 Note The sottware can be made avallable on request
} 

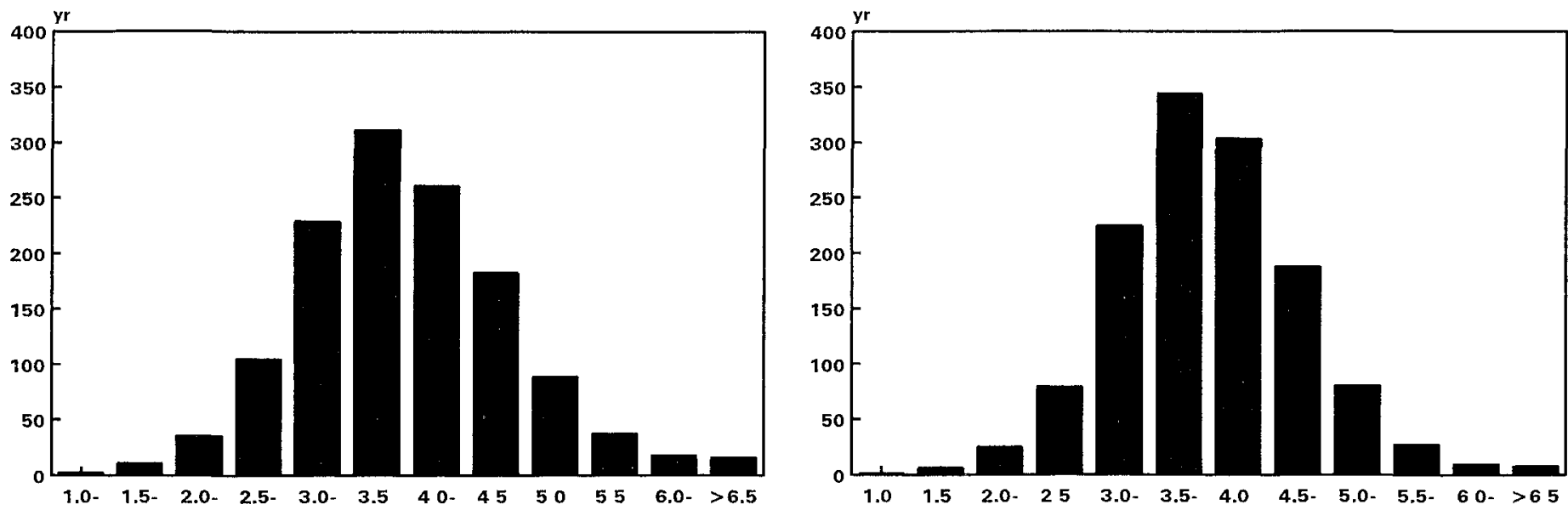

Fig 2 Allocation of INR specilic peison-time of 392 patients with mechanical heait valves The achicved intensity, in peison yeais at ditferent INR values, is shown for 392 patients (1 297 patient years) with mechanical heart valves who were followed betwecn 1985 and 1991 For the upper part of the tiguic, the appioach depicted in Fig 1 has becn cmployed, in which halt of the time elapsed betwecn two visits is allocated to the tisst, and halt to the second measuiement For the lower pait the appioach of a ti uly linear incicase or deciease was used, in which the INR is calculated for each day of the interval For both paits of the trgure, the iesults have been 1 egiouped in 05 INR intervals, and the days have becn conveited to jedis

1.297 ycais) Both approaches yicld very similar icsults, albcit that with the appioach in which the time between two measuicments is divided in halves, slightly mote peison-tıme is accumulated at the extıeme values

\section{Analysts}

Since the number of events at each intensity and the summed persontıme at cach intensity atc now known, incidence 1 ates at each intensity can be calculated The cells may be turther stiatified by scx, age and other covariates, and by application of a multivariate Porsson iegicssion model incidence late ratios at the different intensities may be calculated, to contiol tor confounding by this covariates and to examine the risk of complications associated with these covariates Standard criors for the inerdence 1 ates and the inerdence 1 ate 1 atios can be derived in the standard fashion based on the assumption of a Poisson distilbution of the number of events These multivarute dnalyses can be peitormed by several of the commeicially avalable soltwaıc packages

\section{Applacation of the Method}

This method can be applied ıetıospectively, on data ioutmely icgistered by a thiombosis seivice, as well as piospectively as a secondaty analysis within a iandomized tial The method is piesently cmployed in two studies In the first one, the Leiden Aitificial Valves and Anticoagula tion study (LAVA), we seck the optumal intensity of achreved anticoagu lation in patients with mechanical hedit valves as the level at which the incidence of stioke, combining intaiction and bleeding, is lowest Since the 11sk of thiombosis on a mechanical valve and subsequent ceicbial cmboltsm is high in the absence of anticoagulation ticatment (appioximatcly $1-5 \%$ pei yeal), patients with mechanical heat valves atc intenscly anticoagulated (taiget range in The Netherlands 36-4 8 INR) This implies that the 1isk of major bleedings, of which ccicbial hemo1 lhage is the most severe, is relatively high, and the balance between thiombosis prophylaxis and isk of blceding piccious It is icasonable to assume that the isk of ceicbial cmbolism and intaiction incieases with lower intensities of anticodgulation, whercas the risk of cercbial blecding increases with highei intensitics (Fig 3) So, we expect that the incidence of stroke will have a U-shaped distıbution over the 1 ange of achieved intensitics Picliminaiy icsults indicate that this U-shaped distiıbution does exist (7) For this analysis, it is not even necessary to distinguish between ceicbial intactions and cerebial bleeding and it avoids the difficult task of classitying a hemoit hagie inlaiction as either intaiction or blecding Since we aic interested in the level of anticodgulation that has the lowest iss of stioke, whatever its origin, it is of moie iclevance to use a clinical classification system based on the seventy of the sequelac of the stıoke
In the sccond study, we use this method to investigate isk factors tor bleeding in unselected patients who recerve anticoagulant treatment for various indication (8) To this cftect, we study minor and major bleeding complications duing 1 yeai in the over 6,800 patients ticated by the Leiden Thiombosis Service annually In this instance, the method scives two purposes First we examıne the usk of blecding for different intensities of anticodgulation Second we can by multivaitate analysis, use the intensitics as an adjustment factor and investigate the contribution ot other factors to the isk of bleeding independent of the achicved intensity of anticodgulation

Yet another application of this method is as a measuic for the quality of anticoagulation monitoing which is now usually given as the peicent age of prothiombin times within the tatget zones By calculating the peison-time spent at each intensity of anticoagulation we can expicss the quality of monitoring as the peicentage of the total peison time that lics within the taiget zones

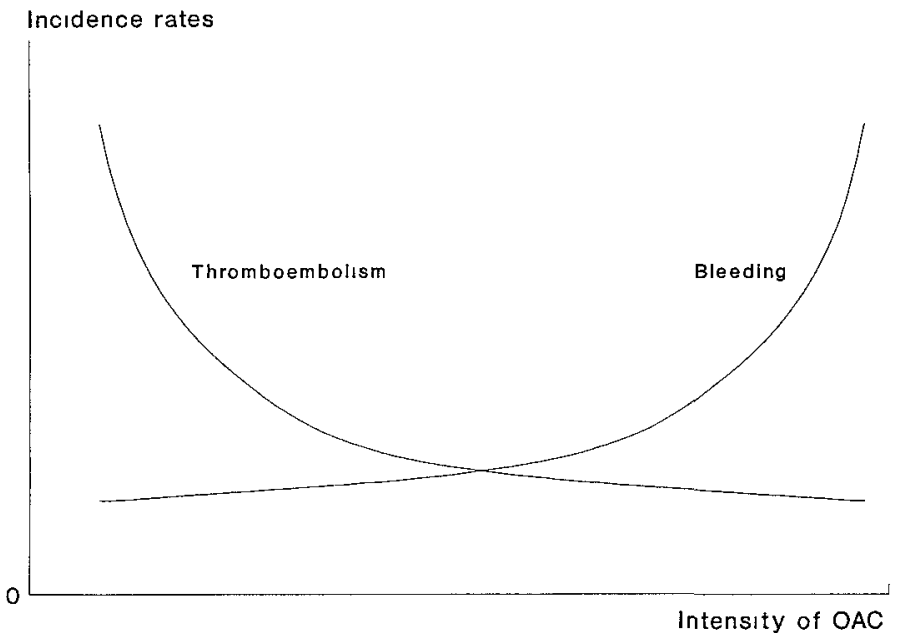

Frg 3 Theoretical iclation of the incidence of thiomboembolism and blceding with the achicved intensity of anticoagulation The 1isk of thiomboembolism decicases exponentially with incieased intensities of anticoagulation, wheieas the isk of bleeding incicases exponentially The lowest incidence of untoward effects $1 \mathrm{c}$ the minimum of the superim posed giaphs, denotes the optimal intensity of anticoagulation 


\section{Discussion}

We have proposed a method that allows assessment of the optimal achieved intensity of anticoagulation by the calculation of INR-specific incidence rates of untoward events The results of analysis by this method can be used to set the target ranges for clinical tiıals on oral anticoagulation tor various indications In addition, the method can be employed to determine isk factors for complications, thiombosis or blecding, adjusted for the achieved level of anticoagulation

A prerequisite for the use of this method is careful observation of all complication If, however, this is done routinely, as in the Dutch Thiombosis Services, and if dates and iesults of prothrombin time medsurements are stored in computeis over longer periods of time, this method can be applicd retiospcctively to large numbers of patıents, and precise estimates may be expected

One of the assumptions of the allocation of person-time to different intensitics of anticoagulation is a linear increase or decrease of the anticoagulation effect between subsequent measurements It may well be, however, that the change is greatest shortly after a measulement has been performed and a dose adjustment has been made, in particular when a prothrombin mcasurement shows excessive under- or overanticoagulation, in which case a boostei-dose or vitamin $\mathrm{K}$ may be prescribed We feel that these effects will probably even out in the broad range around the target values, encompassing the majority of measurcments This is especially so since the INR categoiles are broadly chosen, with intervals of 05 or 10 INR For extreme values, there may be a bias, with an overestimate of the person-time at very low, and at very high INR values This implies that the incidence rates at thesc extremes will be underestimated Since the optimal level will not be located at these extreme values, we consider this of minor importance It must be noted that this reasoning becomes less valid when anticodgulation contiol is of very poo1 quality, 1 e when all stability in anticodgulation is lacking

Assessment of the optimal achieved level of anticoagulation should precede studies comparing different target levels Since it is not possible to maintain an optimal level in all patients constantly, subsequent clinical trials remain nccessa1y, to evaluate target levels set at or around the optimal achieved intensity on an intention-to-treat basis

\section{REFERENCES}

1 Hiss J Oral antıcodgulant diugs N Engl J Med $1991324 \quad 1865-75$

2 International Committec tor Standardication in Hacmatology, Internatronal Committec on Thiombosis and Hacmostasis, ICSH/ICTH recommendations tor 1epoiting piothiombin time in oral anticoagulant contiol Thiomb Hacmostas 1985, 53 155-6

3 Tuipie AGG, Gunstensen J, Hissh J, NeIson H, Gent M Randomised comparison of two intensities of oral anticoagulant therapy after tissuc heart valve i eplacement Lancet 1988, I 1242-5

4 Saouı JN, Sicck JO, Mamo LAR, Gallus AS Tilal of ditferent intensitics on anticoagulation in patients with piosthetic hedit valves N Engl J Med 1990, 322 428-32

5 Breslow NE, Day NE Statistical Methods in Cance1 Rescaich II The Design and Andysis of Cohoit Studies IARC, Lyon 1987 pp 48-79

6 Rothman KJ Modeın Epıdemiology Little, Biown and Company Boston 1986, pp 23-31

7 Cannegieter SC, Rosendaal FR, Biıet E The optımal intensity of oral anticoagulation therapy in patients with prosthetic heait valves (abstiact) Th1 omb Res 1992, 65 (Suppl) 80

8 Van der Meer FJM, Rosendaal FR, Vandenbioucke JP, Biıet E Bleeding complications in ord antıcodgulant theiapy an analysis of 11sk factors Aich Intein Med 1993 (in piess)

Recerved August 11, 1992 Accepted attc1 1cvision November 6, 1992 